\title{
Magnetic petrology and its implication for magma mixing of the 1991-1995 dacite at Unzen volcano, Japan
}

\author{
Takeshi Saito ${ }^{1}$ and Naoto Ishikawa ${ }^{2}$ \\ ${ }^{1}$ Institute for Geothermal Sciences, Kyoto University, Noguchibaru, Beppu, Oita 874-0903, Japan \\ ${ }^{2}$ Graduate School of Human and Environmental Studies, Kyoto University, Yoshida-Nihon-Matsu, Sakyo-ku, Kyoto 606-8501, Japan
}

(Received September 30, 2006; Revised March 16, 2007; Accepted March 23, 2007; Online published July 20, 2007)

\begin{abstract}
Magnetic petrologic analyses were carried out on lava samples from the lava dome of the 1991-1995 eruption of Unzen volcano, Japan. As a result, three kinds of titanomagnetites with different Curie temperatures were identified and the difference between the samples from the lava dome which grew exogenously and endogenously were revealed. Titanomagnetites with $T_{\mathrm{c}}$ of $460-500^{\circ} \mathrm{C}$ and $380-400^{\circ} \mathrm{C}$ are the predominant magnetic minerals. In addition, a titanomagnetite with $T_{\mathrm{c}}$ of $\sim 540^{\circ} \mathrm{C}$, but in low concentration, is also present. The exogenous lava samples contain more titanomagnetite with $T_{\mathrm{c}}$ of $380-400^{\circ} \mathrm{C}$ and less microphenocrysts of titanomagnetites than the endogenous samples. The equilibrium temperature of $900-920^{\circ} \mathrm{C}, 780-820^{\circ} \mathrm{C}$ and $720^{\circ} \mathrm{C}$ is estimated from titanomagnetite with $T_{\mathrm{c}}$ of $380-400^{\circ} \mathrm{C}, 460-500^{\circ} \mathrm{C}$ and $540^{\circ} \mathrm{C}$, respectively. We suggest that these titanomagnetites are probably formed by magma mixing and eruption processes. Titanomagnetite with $T_{\mathrm{c}}$ of $460-500^{\circ} \mathrm{C}$ was derived from felsic magma $\left(780-820^{\circ} \mathrm{C}\right)$ in a shallow chamber. Titanomagnetite with $T_{\mathrm{c}}$ of $380-400^{\circ} \mathrm{C}$ was produced from the mixed magma $\left(900-920^{\circ} \mathrm{C}\right)$. After being squeezed out from the reservoir, a small amount of titanomagnetite with $T_{\mathrm{c}}$ of $\sim 540^{\circ} \mathrm{C}$ was crystallized.
\end{abstract}

Key words: Unzen volcano, lava dome, iron-titanium oxide, magnetic petrology, magma mixing.

\section{Introduction}

Magnetic minerals display a wide variety of chemical and physical features, caused by crystallizing conditions and successive cooling processes. In particular, volcanic materials contain abundant magnetic minerals with wide variations in magnetic properties. By analyzing magnetic minerals, we can estimate magmatic conditions or eruptive and cooling processes. In addition, unlike other rock forming minerals, magnetic minerals exhibit strong and diverse magnetic signals. Therefore, rock magnetic methods are very effective in studying Fe-Ti oxides in igneous rocks.

Recently, studying magnetic signals and magnetic minerals have achieved steady results and such a method of study is known as magnetic petrology (e.g. Frost, 1991; Audunsson et al., 1992; Kontny et al., 2003; Saito et al., 2004a). Magnetic petrology identifies magnetic minerals and determines the factors that control the genesis of magnetic minerals (Saito, 2005). Therefore, magnetic petrology is very useful for studying the genesis and evolution of the materials.

Unzen volcano in southwest Japan is one of the most active volcanoes in Japan. The most recent activity is the 1991-1995 eruption, which is characterized by the effusions of dacite lava domes and the generations of abundant block-and-ash flows of dome collapse origin (e.g. Nakada et al., 1999). This activity was monitored and investigated in detail and is typical of lava dome eruptions. Erupted

Copyright (c) The Society of Geomagnetism and Earth, Planetary and Space Sciences (SGEPSS); The Seismological Society of Japan; The Volcanological Society of Japan; The Geodetic Society of Japan; The Japanese Society for Planetary Sciences; TERRAPUB. magma has been studied by many petrologists (e.g. Sato et al., 1999; Venezky and Rutherford, 1999; Nakada and Motomura, 1999; Holtz et al., 2005; Sato et al., 2005). However, except for Tanaka et al. (2004), there are few magnetic studies of the 1991-1995 lava.

We have undertaken a magnetic petrologic study of the 1991-1995 dacite lava of Unzen volcano in order to clarify the eruption and collapsing processes of a lava dome. Previously, we reported that the variations in magnetic minerals and their oxidation states in the dome lava, was an indication that these variations were produced by redox reactions in the lava dome (Saito et al., 2004b). During the course of analyzing the dome lavas which did not suffer any redox reactions, we found magnetic petrologic characteristics that seemed to be derived from the mixed magma of 1991-1995 eruption. In this paper, we document magnetic petrology of dacite lavas sampled from the lava dome and discuss it in terms of magma mixing of the 1991-1995 eruption.

\section{Geological Setting and Sample Description}

Unzen volcano is located in a volcanotectonic depression, the Unzen graben, on the Shimabara peninsula of Kyushu, Japan (Ohta, 1973; Fig. 1(b)). The Unzen graben composes the western part of the Beppu-Shimabara graben, in which many quaternary volcanoes are concentrated (Matsumoto, 1993). Unzen is a composite volcano of thick andesite-dacite lavas and pyroclastic materials. Its activity, which started about half a million years ago, is characterized by effusions of lava flows and domes and by block-and-ash flows of dome collapse origin (Hoshizumi $e t$ $a l ., 1999)$. In historic time, two lava flows were effused in 


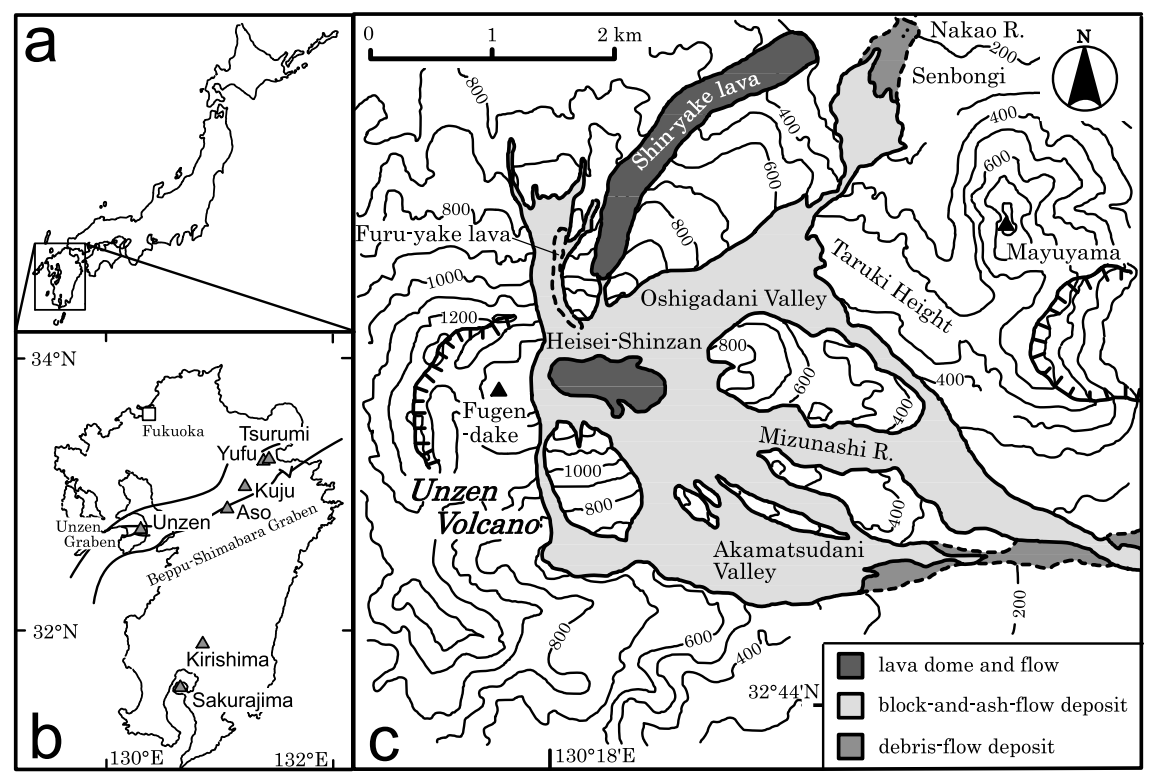

Fig. 1. (a) Simplified map of the Japanese islands. (b) Map of Kyushu island showing major active volcanoes (triangles). The Beppu-Shimabara graben and Unzen graben are outlined by thick lines (Matsumoto, 1993). (c) Simplified geologic map of Unzen volcano after Ui et al. (1999). Distribution of the volcanic deposits during 1991-1995 and two lava flows in historic times is shown.

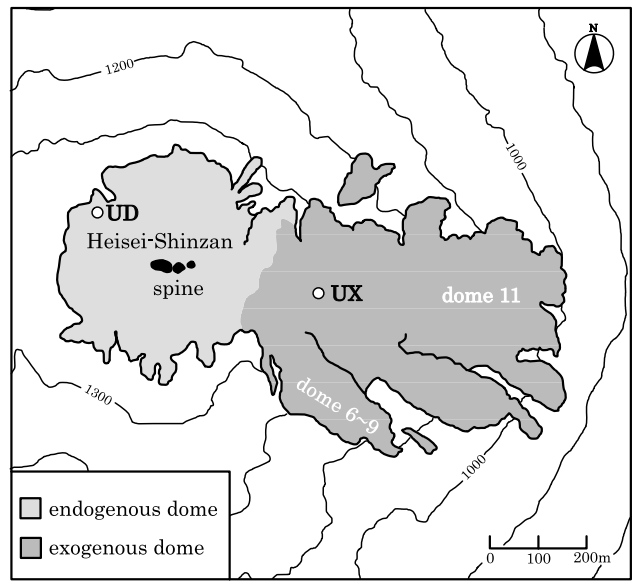

Fig. 2. Simplified map of the lava dome formed in the 1991-1995 eruption (named Heisei-Shinzan). The dome grew exogenously on the eastern slope, while the western part grew endogenously (Nakada et al., 1999). Sampling locations (UD and UX) are shown.

1663 and 1792 . The most recent activity is the lava dome eruption that occurred in 1991-1995 (Fig. 1(c)).

In 1991-1995 eruption, the lava dome was emplaced on the summit of Fugen-dake volcano, which was newly named Heisei-Shinzan (Fig. 2). The dome exhibited two different growth styles. Exogenous growth occurred when new lava was squeezed out from the vent and slowly spread laterally. Endogenous growth occurred when new magma was intruded within the dome and no new lava was extruded on the surface of the dome (Ui et al., 1999). The exogenous growth occurred when the effusion rate of the lava was high, while the endogenous growth occurred when the effusion rate was low (Nakada et al., 1999).

The western part of the dome is covered with abundant large lava blocks of several meters in diameter, which were supplied during the final stage of endogenous growth. The exogenous dome is mainly emplaced on the eastern slope of Fugen-dake volcano. Although a large part of the dome lost its initial structure due to partial collapsing or successive intrusions of endogenous dome, in some localities initial structures still remain. Around the vent area of dome 11, the lava dome exhibits some flows with smooth surfaces.

Lava blocks were sampled from the dacitic lava dome with different growth styles (Fig. 2). Eight exogenous dome samples (UX1-8) were taken from the vent area of dome 11. Six endogenous dome samples (UD1-6) were taken from the western part of the dome. We selected fresh lavas, which did not suffer any redox or secondary reactions, for sample collection. The dome lava is a plagioclase-phyric dacite $\left(\mathrm{SiO}_{2}\right.$ 64.5-66.0 wt.\%), containing phenocrysts of plagioclase, hornblende, biotite, quartz, Fe-Ti oxides and pyroxene (Nakada et al., 1999). The endogenous dome lava shows higher groundmass crystallinity than the exogenous dome lava (Nakada and Motomura, 1999).

\section{Rock Magnetic Analyses \\ 3.1 Experimental procedures}

Almost all the rock magnetic analyses were carried out in the rock magnetic laboratory at Graduate School of Human and Environmental Studies, Kyoto University. For the experiments, specimens of $25 \mathrm{~mm}$ diameter and $22 \mathrm{~mm}$ height were cut from the lava samples. For thermomagnetic analyses and high-temperature susceptibility measurements, rock samples were crushed and small chips were prepared.

Thermomagnetic analyses were performed on rock chips of $\sim 30 \mathrm{mg}$ using a horizontal thermomagnetic balance. The samples were heated up to $600^{\circ} \mathrm{C}$ and cooled in air, in an applied field of 0.2-0.4 T. Some experiments were carried out in an argon atmosphere in order to assess the thermal alteration during the heating. The heating and cooling rates were about $8^{\circ} \mathrm{C} / \mathrm{min}$. Curie temperatures $\left(T_{\mathrm{c}}\right)$ were estimated by the differential method (Tauxe, 1998). 

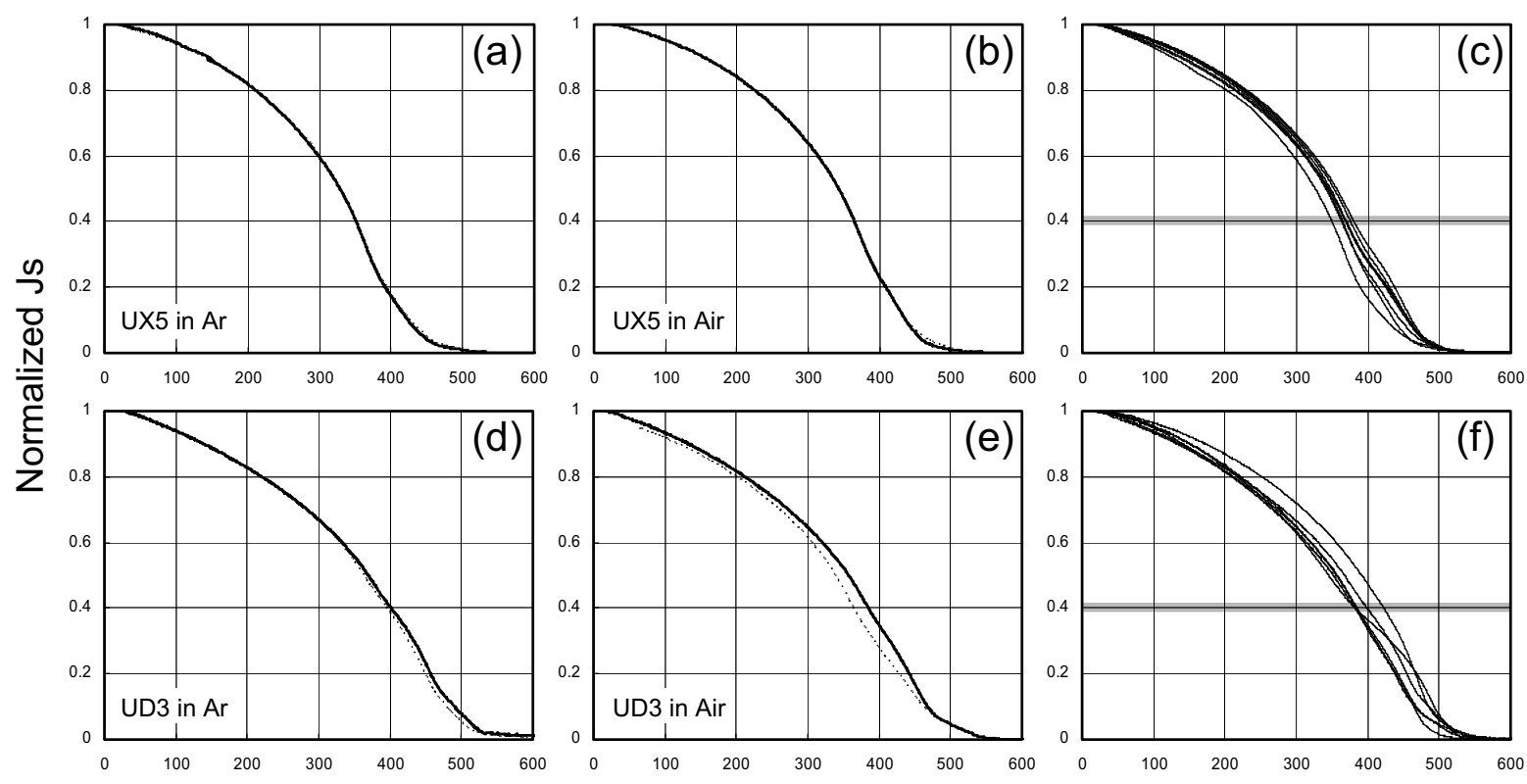

TEMPERATURE $\left({ }^{\circ} \mathrm{C}\right)$

Fig. 3. Representative thermomagnetic curves of the exogenous dome samples (UX5) in an argon atmosphere (a) and in air (b) and the curves of the endogenous dome samples (UD3) in an argon atmosphere (d) and in air (e). Solid and dashed lines indicate heating and cooling curves, respectively. (c) and (f) All heating curves of exogenous and endogenous samples in air. Each curve was normalized by its initial value.

High-temperature susceptibility measurements were performed on rock chips of $\sim 1.5 \mathrm{~g}$ using a furnace attachment to a Bartington MS2 susceptibility meter. The samples were heated up to $\sim 660^{\circ} \mathrm{C}$ and cooled in air. The heating and cooling rates were about $8^{\circ} \mathrm{C} / \mathrm{min}$. Some experiments were carried out under an argon atmosphere by using a Kappabridge KLY-3S susceptibility meter with the CS-3 furnace apparatus of AGICO at Science and Engineering Research Institute, Doshisha University. The heating and cooling rates were about $11^{\circ} \mathrm{C} / \mathrm{min}$.

Acquisition and demagnetization experiments of artificial remanences, anhysteretic remanence (ARM) and isothermal remanence (IRM), were performed. For the measurements of ARM and IRM, we used a spinner magnetometer (Natsuhara-Giken SMM-85). ARM was imparted at $100 \mathrm{mT}$ alternating field with a $0.1 \mathrm{mT}$ direct field. IRM was given with a pulse magnetizer (Magnetic Measurements MMPM-10) up to maximum fields of 1.7 T. Before remanence acquisition, samples were demagnetized in an alternating field of $100 \mathrm{mT}$ using a Natsuhara-Giken AF demagnetizer (DEM-8601M) with a three-axis tumbler system. Then, progressive alternating-field demagnetization (PAFD) of each artificial remanence was carried out up to a peak alternating field of $100 \mathrm{mT}$. After PAFD experiments, progressive thermal demagnetization (PThD) of orthogonal IRMs (Lowrie, 1990) was carried out. The orthogonal IRM was produced by applying a direct field of $1.7 \mathrm{~T}$ along the $z$-axis, followed by $0.4 \mathrm{~T}$ along the $y$-axis and finally $0.12 \mathrm{~T}$ along the $x$-axis. Then, PThD was carried out up to $580^{\circ} \mathrm{C}$ in air using an electric furnace in a three-layer $\mu$-metal magnetic shield. The residual field in the furnace is less than 7 nT.

\subsection{Thermomagnetic analyses}

All measured curves for Unzen samples showed completely reversible shapes (Fig. 3). There was no significant difference between the results in air and argon atmosphere, indicating that significant thermal alteration did not occur during the heating. All the heating curves showed two distinct inflections at $380-400^{\circ} \mathrm{C}$ and at $460-500^{\circ} \mathrm{C}$. Some endogenous samples showed another inflection above $500^{\circ} \mathrm{C}$ (Fig. 3(d) and (e)) but this signal was not clear in the other samples. Induced magnetization $\left(J_{\mathrm{s}}\right)$ of the exogenous dome samples decreased below $40 \%$ of the initial value up to low $T_{\mathrm{c}}$, while those of the endogenous curves remained above $40 \%$ (Fig. 3(c) and (f)). The data indicated that the Unzen samples contain two kinds of magnetic minerals with different $T_{\mathrm{c}}\left(380-400^{\circ} \mathrm{C}\right.$ and $\left.460-500^{\circ} \mathrm{C}\right)$ and the relative amounts of the two magnetic minerals differ between the exogenous and endogenous samples.

\subsection{High-temperature susceptibility}

Susceptibility curves did not show so reversible shapes as thermomagnetic curves did (Fig. 4). This is probably due to thermal alteration of magnetic minerals during the experiments. However, both heating and cooling curves showed same characters as described later. Therefore we think the characters are intrinsic.

All measured curves of Unzen samples showed three distinct inflections (Fig. 4). Susceptibility curves gently increased up to $300^{\circ} \mathrm{C}$ and then dropped rapidly above 350 $380^{\circ} \mathrm{C}$, implying the presence of magnetic minerals with $T_{\mathrm{c}}$ of $380-400^{\circ} \mathrm{C}$. Above $400^{\circ} \mathrm{C}$, the decrease of the curves became more gentle and small plateaus occurred around 400 $450^{\circ} \mathrm{C}$. The curves fell again above $450^{\circ} \mathrm{C}$, probably due to magnetic minerals with $T_{\mathrm{c}}$ of $460-500^{\circ} \mathrm{C}$. Finally the susceptibility dropped to the lowest value around $500-550^{\circ} \mathrm{C}$, suggesting the existence of still another magnetic mineral 

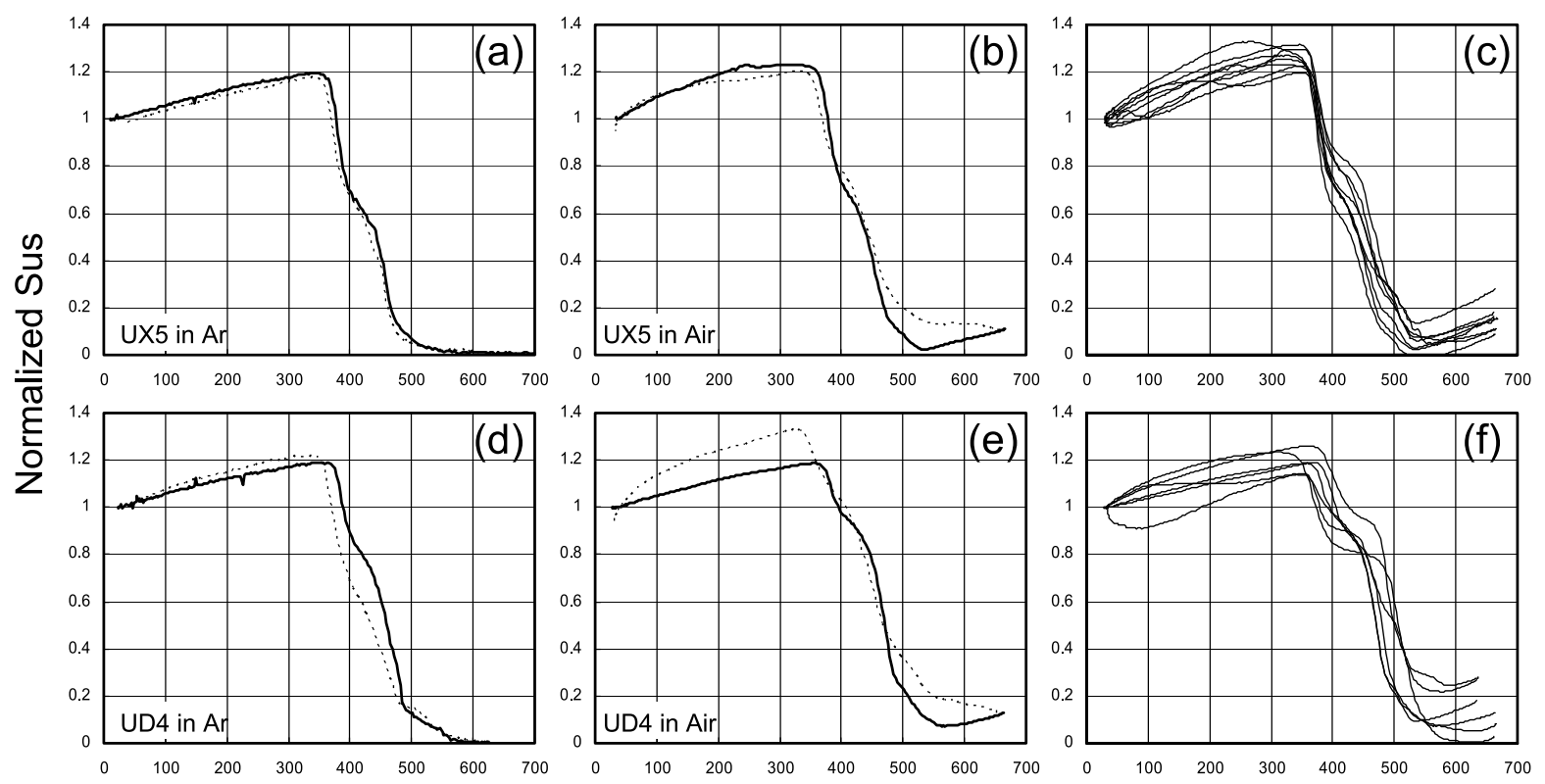

TEMPERATURE $\left({ }^{\circ} \mathrm{C}\right)$

Fig. 4. Representative temperature-susceptibility curves of the exogenous dome samples (UX5) in an argon atmosphere (a) and in air (b) and the curves of the endogenous dome samples (UD4) in an argon atmosphere (d) and in air (e). Solid and dashed lines indicate heating and cooling curves, respectively. (c) and (f) All heating curves of exogenous and endogenous samples in air. Each curve was normalized by its initial value.

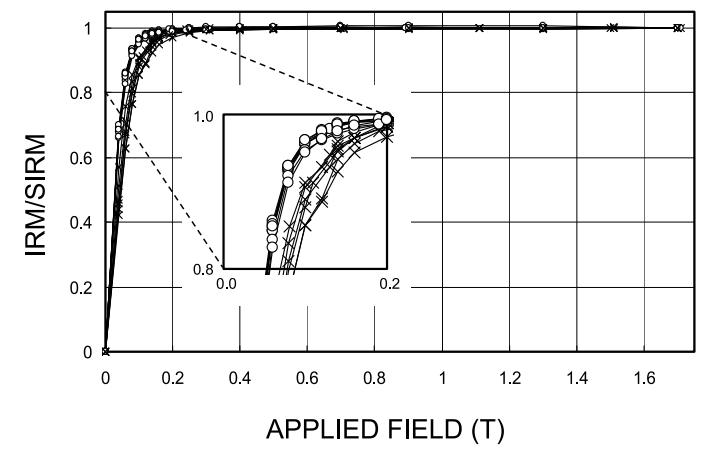

Fig. 5. Normalized IRM acquisition curves for the exogenous dome samples (circles) and the endogenous dome samples (crosses) in fields up to $1.7 \mathrm{~T}$. Insert shows the acquisition curves up to $0.2 \mathrm{~T}$.

with high $T_{\mathrm{c}}$, although all thermomagnetic results did not indicate a clear signal above $500^{\circ} \mathrm{C}$ (Fig. 3). The amount of the first drop at $350-400^{\circ} \mathrm{C}$ for the exogenous samples is greater than that for the endogenous samples. This is consistent with the result of thermomagnetic analyses, indicating that relative amounts of magnetic minerals with the lowest $T_{\mathrm{c}}$ in the exogenous samples are grater than those in the endogenous samples.

\subsection{Acquisition and demagnetization of IRM and ARM}

IRM acquisition curves for Unzen samples rose very steeply initially and reached over $95 \%$ of saturation by 0.2 $\mathrm{T}$ (Fig. 5). Complete saturation was achieved by $0.3 \mathrm{~T}$, indicating titanomagnetite as the predominant magnetic mineral. The curves of the exogenous samples lay above those of the endogenous samples. It is suggested that titanomagnetites with slightly higher coercivities in the endogenous samples make a greater contribution to the remanences than those in the exogenous samples.

PAFD curves of ARM always lay above those of IRM, indicating SD-like behavior (Fig. 6). The endogenous samples showed higher medium destructive fields for both artificial remanences than the exogenous samples. This also suggests that higher coercivity grains in the endogenous samples make a larger contribution to the remanences than those in the exogenous samples.

The orthogonal IRM were completely demagnetized by $540^{\circ} \mathrm{C}$ (Fig. 7). The soft coercivity $(<0.12 \mathrm{~T})$ fraction carried most of the IRM and little magnetization remained with the hard fraction $(0.4-1.7 \mathrm{~T})$. This suggests that titanomagnetite is the predominant magnetic mineral rather than antiferromagnetic phases like hematite or titanohematite. There was a kink at $400^{\circ} \mathrm{C}$ on the curves of soft and median fraction of the exogenous dome samples (Fig. 7(a)), indicating another titanomagnetite with a different Ti content. On the other hand, the soft fraction of the endogenous sample was demagnetized smoothly to zero by $540^{\circ} \mathrm{C}$ (Fig. 7(b)). The median fraction of the endogenous samples made a larger contribution to the remanence than that of exogenous samples, suggesting the larger contribution of higher coercivity grains in the endogenous samples.

\section{Microscopic Observation}

In order to examine the existence and occurrence of magnetic minerals, microscopic observation was carried out on the lava samples. Polished thin sections were examined by optical microscopy in reflected light. As a result, various $\mathrm{Fe}-\mathrm{Ti}$ oxide minerals were identified. Incidentally, there are many oxidized lavas at the Unzen dome, which contain FeTi oxide minerals oxidized to various degrees. Their occurrences and characteristics were described in detail by Saito et al. (2004b). In this study, we eliminated these oxidized 

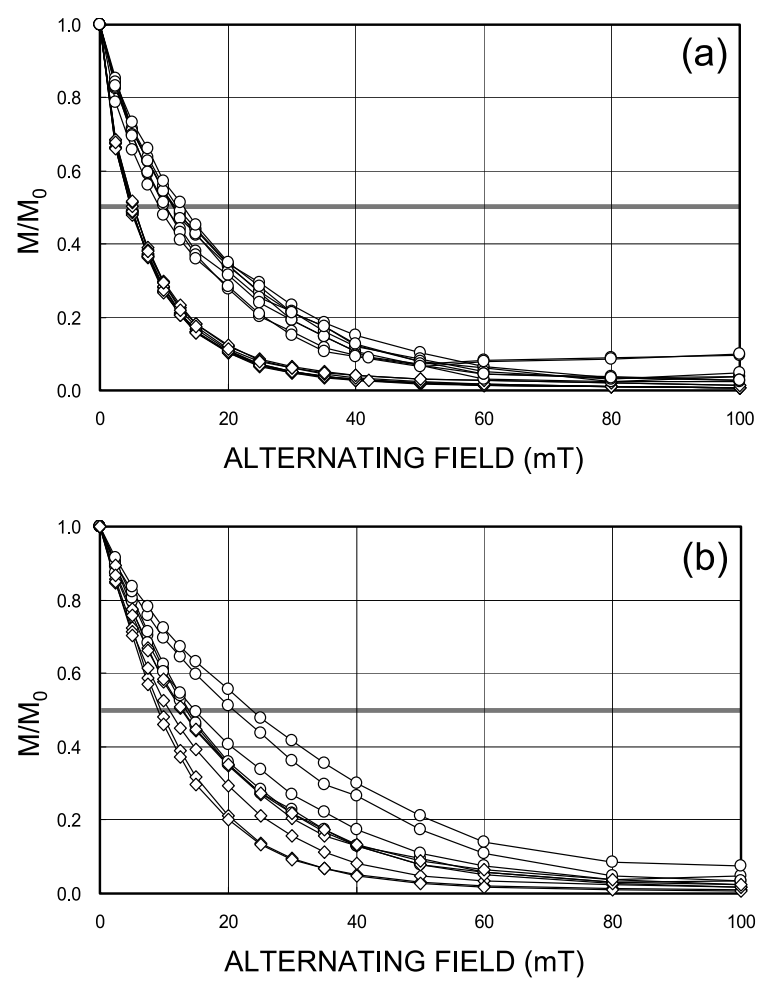

Fig. 6. Normalized PAFD curves of ARM (circles) and SIRM (diamonds) for the exogenous samples (a) and endogenous samples (b). ARM was produced by applying a direct field of $0.1 \mathrm{mT}$ in a peak alternating field of $100 \mathrm{mT}$. IRM was imparted in $1.7 \mathrm{~T}$.

samples on the basis of petrologic observation.

$\mathrm{Fe}-\mathrm{Ti}$ oxide minerals in our samples were characterized by homogeneous titanomagnetite and titanohematite. Hematite or iron sulphide was not identified. This is consistent with the rock magnetic results. Titanomagnetite and titanohematite occur as phenocrysts up to about $0.5 \mathrm{~mm}$ across. They are optically homogenous discrete crystals without lamellas. Some titanomagnetite grains mantle with or attach to titanohematite. Small microphenocryst-sized crystals are found in the groundmass. The endogenous dome samples show higher groundmass crystallinity than the exogenous samples do. The groundmass of the exogenous samples is glassy. The endogenous samples contain larger amounts of titanomagnetite and titanohematite microphenocrysts in the groundmass than the exogenous samples.

\section{Discussion}

\subsection{Magnetic mineralogy}

Our results indicate the existence of more than one magnetic mineral. Reversible shapes of thermomagnetic curves indicate titanomaghemite is not contained (Fig. 3). Although susceptibility curves showed slightly irreversible shapes (Fig. 4), it is hard to say that titanomaghemite contributes the magnetic signals. There is no indication of the existence of magnetic minerals with high coercivity, such as hematite. Although titanohematite phenocrysts were observed in the thin sections, the titanohematites are inferred to have high Ti content and to be thus non-magnetic at and above room temperature. Previous petrologic studies re-
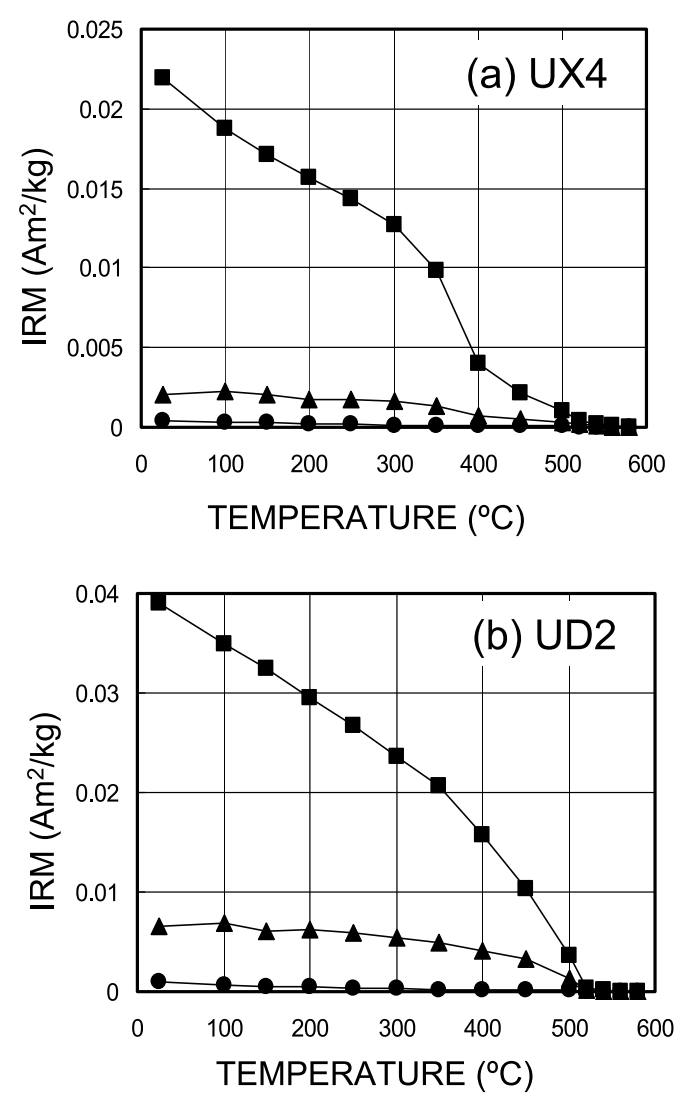

Fig. 7. Typical PThD results of the orthogonal IRM. (a) is the result of the exogenous dome samples (UX4) and (b) is the endogenous samples (UD2). The orthogonal IRM was produced by magnetizing the sample in $1.7 \mathrm{~T}$ along the $z$-axis (circles), followed by $0.4 \mathrm{~T}$ along the $y$-axis (triangles) and then $0.12 \mathrm{~T}$ along the $x$-axis (squares).

ported the existence of titanohematite with high Ti content of $\sim 0.8$ in the dome samples of the Unzen volcano (Nakamura, 1995; Venezky and Rutherford, 1999; Nakada and Motomura, 1999). Therefore we conclude magnetic minerals are titanomagnetites with different character.

Thermomagnetic analyses revealed the presence of two kinds of titanomagnetite with $T_{\mathrm{c}}$ of $380-400^{\circ} \mathrm{C}$ and 460 $500^{\circ} \mathrm{C}$. In addition to the two titanomagnetites, hightemperature susceptibility measurements suggested the existence of another titanomagnetite with higher $T_{\mathrm{c}}$ above $500^{\circ} \mathrm{C}$. The orthogonal IRM did not demagnetized completely below $500^{\circ} \mathrm{C}$ and complete demagnetization occurred at $540^{\circ} \mathrm{C}$, which also indicate the existence of titanomagnetite with $T_{\mathrm{c}}$ of $\sim 540^{\circ} \mathrm{C}$.

Although the presence of three kinds of titanomagnetites with different $T_{\mathrm{c}}$ values were suggested based on the thermal behaviors of $J_{\mathrm{s}}$, susceptibility and IRM, all samples did not show all of the magnetic signals of the three titanomagnetites. The different behaviors in the thermal experiments may be caused by the difference in relative amounts of the three magnetic minerals in the samples. The thermomagnetic results did not indicate the presence of the high$T_{\mathrm{c}}$ titanomagnetite clearly. The amount of the high- $T_{\mathrm{c}}$ titanomagnetite seems to be very small. The signals of the low- and middle- $T_{\mathrm{c}}$ titanomagnetites were clearly detected. The two titanomagnetites are therefore regarded as the main magnetic minerals. In addition, the lower the $T_{\mathrm{c}}$ of titano- 


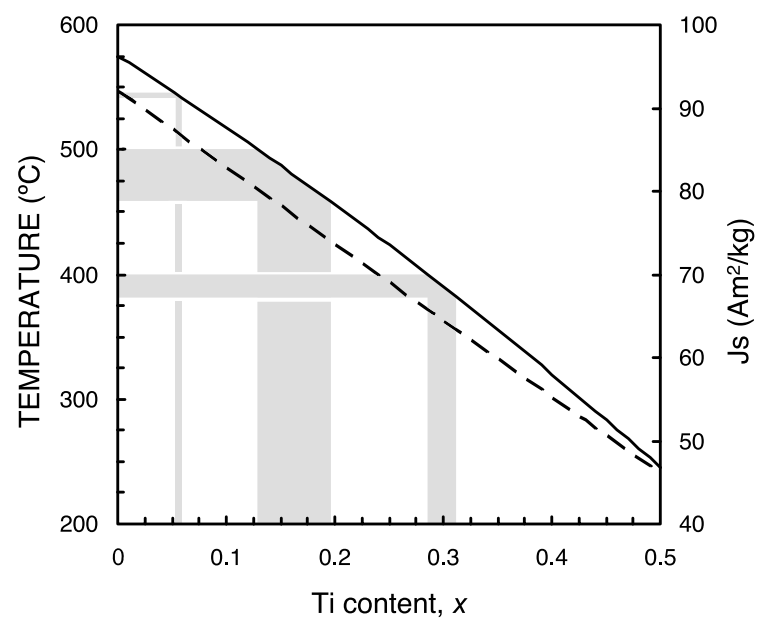

Fig. 8. Curie temperature (solid line) and saturation magnetization (dashed line) of titanomagnetite as a function of Ti content $x$ after Hunt et al. (1995). The values of titanomagnetites in Unzen samples are also shown as grey bars.

magnetite becomes, the lower its saturation magnetization (e.g. Dunlop and Özdemir, 1997; Fig. 8). $J_{\mathrm{s}}$ of the low$T_{\mathrm{c}}$ titanomagnetite is about $70 \%$ of that of the high- $T_{\mathrm{c}}$ titanomagnetite. This implies that the ratio of the amount of the low- $T_{\mathrm{c}}$ titanomagnetite to the other titanomagnetites is actually higher than the apparent ratio indicated by the $J_{\mathrm{S}}$ (Fig. 3) and IRM (Fig. 6) curves.

The orthogonal IRM results of the endogenous samples did not show clear signals from the low- $T_{\mathrm{c}}$ titanomagnetite, while the exogenous samples showed a large drop at $400^{\circ} \mathrm{C}$ (Fig. 7). The thermomagnetic and high-temperature susceptibility results indicated that the low- $T_{\mathrm{c}}$ titanomagnetite makes a greater contribution to $J_{\mathrm{s}}$ or susceptibility in the exogenous samples than the endogenous ones (Figs. 3 and 4). It is inferred that the endogenous samples do not contain as much of the low- $T_{\mathrm{c}}$ titanomagnetite as the exogenous samples.

We conclude that Unzen samples contain three kinds of titanomagnetites, whose $T_{\mathrm{c}}$ is about $380-400^{\circ} \mathrm{C}, 460$ $500^{\circ} \mathrm{C}$ and $\sim 540^{\circ} \mathrm{C}$ respectively. The lowest and middle $T_{\mathrm{c}}$ titanomagnetites are predominant compared to the highest $T_{\mathrm{c}}$ titanomagnetite. The exogenous samples contain larger amount of titanomagnetite with the lowest $T_{\mathrm{c}}$ than the endogenous samples.

\subsection{Magnetic granulometry}

Acquisition and demagnetization of IRM and ARM experiments indicated that the contribution of the higher coercivity grains differ between the endogenous and exogenous samples. All the results from the endogenous samples showed larger contribution of the higher coercivity grains to the remanence than those from the exogenous samples. Generally speaking, the smaller grain size of titanomagnetite becomes, the higher its coercivity becomes (e.g. Dunlop and Özdemir, 1997). This suggests that the dominant grain size of titanomagnetite in the endogenous samples is smaller than that in the exogenous samples.

The ratio of susceptibility to SIRM (Thompson and Oldfield, 1986) is also useful for estimating magnetic granulometry. While initial susceptibility values of both samples

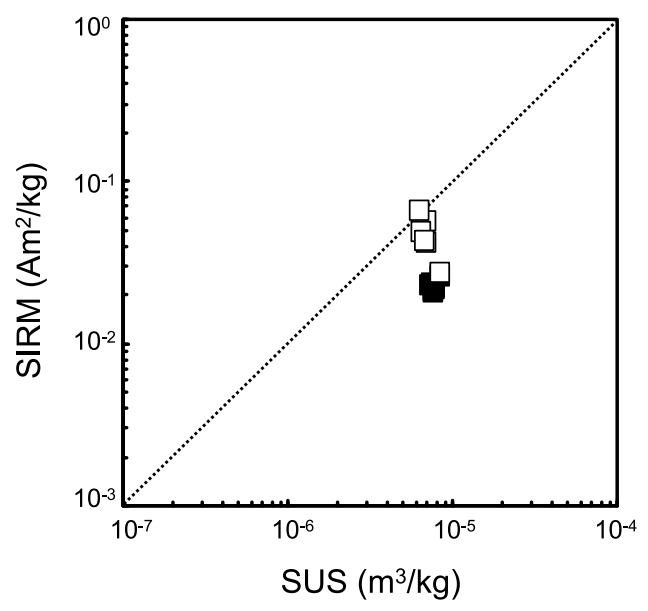

Fig. 9. Bilogarithmic susceptibility versus SIRM plot for the exogenous samples (solid squares) and the endogenous samples (open squares). High concentrations of magnetic minerals plot towards the top right and small grains plot towards the top (Thompson and Oldfield, 1986).

were concentrated in the range $6.3-8.5 \times 10^{-6} \mathrm{~m}^{3} / \mathrm{kg}$, SIRM values were relatively scattered (Fig. 9). The endogenous samples showed higher SIRM values than the exogenous ones. It is implied that the dominant grain size are smaller in the endogenous samples than the exogenous ones.

These results are consistent with microscopic observation. Microscopic observation revealed that the endogenous samples contain larger amount of titanomagnetite microphenocrysts than the exogenous samples. The exogenous samples lack these small microphenocrysts, resulting in glassy groundmass. This difference between the endogenous samples and exogenous samples seems to cause the difference in the dominant grain size.

\subsection{Genesis of magnetic minerals}

Curie temperature of titanomagnetite depends on Ti content $x . X$ values of Unzen titanomagnetites were estimated from their $T_{\mathrm{c}}$ by using the equation of Hunt et al. (1995). Ti contents of titanomagnetite with $T_{\mathrm{c}}=540^{\circ} \mathrm{C}, 460-500^{\circ} \mathrm{C}$ and $380-400^{\circ} \mathrm{C}$ were estimated to be about $0.06,0.13-0.19$ and 0.29-0.31, respectively (Fig. 8).

Ti content of titanomagnetite in Unzen lava was previously reported by some petrologic works. Nakamura (1995) reported that the $\mathrm{Ti}$ content of titanomagnetite were with $0.17<x<0.23$. Venezky and Rutherford (1999) reported the values of $0.14<x<0.32$, while Nakada and Motomura (1999) reported the value of $0.17<x<0.35$. These values from petrologic studies are consistent with two titanomagnetites with $0.13<x<0.19$ and $0.29<x<0.31$ in our study. However, the value of 0.06 is not reported by any previous works. We think this is because this particular titanomagnetite occurs in very low concentrations. In addition, this titanomagnetite possibly occurs as small microphenocryst in the groundmass. As described later, this Ti-poor titanomagnetite shows the lowest equilibrium temperature, suggesting it was crystallized as microphenocrysts just before the eruption. The chemical compositions of small microphenocryst are usually difficult to determine by an electron microprobe analyzer (smaller than 2-3 $\mu \mathrm{m}$, the spot size of the beam). Therefore, this titanomag- 
Table 1. Characteristics of three titanomagnetites in Unzen dacite. Ti content $x$ was evaluated by using the equation of Hunt et al. (1995). Equilibrium state was estimated by a two-oxide geothermobarometer (Spencer and Lindsley, 1981).

\begin{tabular}{cccc}
\hline \multicolumn{3}{c}{ Three titanomagnetites } \\
\hline$T_{\mathrm{c}}\left({ }^{\circ} \mathrm{C}\right)$ & $380-400$ & $460-500$ & 540 \\
Ti content $x$ & $0.29-0.31$ & $0.13-0.19$ & 0.06 \\
Temp $\left({ }^{\circ} \mathrm{C}\right)$ & $900-920$ & $780-820$ & 720 \\
$\log _{10} f_{\mathrm{O}_{2}}$ & -10.5 & -12 & -13 \\
\hline
\end{tabular}

netite might not be identified by previous petrologic studies. On the other hand, rock magnetic analyses are effective for even small grains because small grains show strong magnetism; grains with submicron sizes exhibit SD behavior. This may be the reason why we can detect the titanomagnetite.

Next, equilibrium states were estimated by a two-oxide geothermobarometer (Spencer and Lindsley, 1981). This estimation needs Ti content $y$ of coexisting titanohematite. It is noted that titanohematite in the Unzen dacite is relatively homogenous with respect to Ti content, while Ti content of titanomagnetite is widely distributed and shows reverse zoning (Nakamura, 1995). Previous petrologic studies reported the chemical compositions of titanohematite were with $0.79<y<0.82$ (Nakamura, 1995), $0.73<y<$ 0.78 (Venezky and Rutherford, 1999) and $0.79<y<0.83$ (Nakada and Motomura, 1999). For our calculations, we adopted a $y$ value of 0.8 . Although uncertainty about the $y$ value obscures the estimation, qualitative tendency is plausible and we believe the following estimation is worth discussing.

As a result, equilibrium temperature of $900-920^{\circ} \mathrm{C}, 780$ $820^{\circ} \mathrm{C}$ and $720^{\circ} \mathrm{C}$ was estimated from titanomagnetite with $0.29<x<0.31,0.13<x<0.19$ and $x=0.06$, respectively, at an oxygen fugacity of $2 \log$ unit higher than the NNO buffer (Table 1). It is suggested that three titanomagnetites with different $T_{\mathrm{c}}$ were produced in different equilibrium states. The lower the $T_{\mathrm{c}}$ of titanomagnetite becomes, the higher its equilibrium temperature.

\subsection{Implications for magma mixing of the 1991-1995 Unzen dacite}

Our study suggested that Unzen samples have three titanomagnetites with different equilibrium states and the relative amounts of these titanomagnetites differ between the exogenous dome samples and endogenous samples. Finally, we discuss our results in terms of magma mixing during the 1991-1995 eruption.

Under the Unzen volcano, several magma chambers exist according to GPS measurements (Nishi et al., 1999) and seismologic analyses (Umakoshi et al., 2001). Petrologic studies showed that magma mixing occurred during the 1991-1995 eruption (e.g. Nakamura, 1995; Nakada and Motomura, 1999; Holtz et al., 2005; Sato et al., 2005). Although there are still some controversial points, such as precise positions of magma chambers or detailed processes of magma mixing, the following scenario is widely accepted. High temperature mafic and aphyric magma in a deep magma chamber was intruded into low temperature felsic and phyric magma in a shallow chamber. Magma mixing occurred in the shallow chamber and erupted magma was produced.

Two main titanomagnetites with $T_{\mathrm{c}}=460-500^{\circ} \mathrm{C}$ and $380-400^{\circ} \mathrm{C}$ yielded the equilibrium temperature of 780 $820^{\circ} \mathrm{C}$ and $900-920^{\circ} \mathrm{C}$, respectively. These temperatures correspond with the temperature of the 1991-1995 magma. According to Holtz et al. (2005), the temperature of mafic and felsic magma is about $1050^{\circ} \mathrm{C}$ and $760-780^{\circ} \mathrm{C}$ and the erupted magma of $870-900^{\circ} \mathrm{C}$ was produced by magma mixing. The equilibrium temperature from titanomagnetite with $T_{\mathrm{c}}=460-500^{\circ} \mathrm{C}$ and $380-400^{\circ} \mathrm{C}$ is close to the temperature of felsic magma and mixed magma, respectively. This suggests that titanomagnetite with $T_{\mathrm{c}}=460-500^{\circ} \mathrm{C}$ is derived from felsic magma and the mixed magma produced titanomagnetite with $T_{\mathrm{c}}=380-400^{\circ} \mathrm{C}$. Incidentally, high temperature mafic magma is aphyric and contain little titanomagnetite, resulting in no indication in our study.

Titanomagnetite with $T_{\mathrm{c}}=\sim 540^{\circ} \mathrm{C}$ showed the lowest equilibrium temperature of $720^{\circ} \mathrm{C}$, which is lower than magmatic temperature. This titanomagnetite may be produced after being squeezed out from the chamber. A temperature of $670^{\circ} \mathrm{C}$ was measured from the surface of the lava dome (Taniguchi et al., 1996). The temperature of $720^{\circ} \mathrm{C}$ is suitable for the temperature of the conduit or the inner part of the dome. Nakada et al. (1999) indicated that a minor amount of groundmass crystallization continued after dome formation, though most crystallization was completed before the magma reached the conduit top. Small amounts of titanomagnetite with $T_{\mathrm{c}}=\sim 540^{\circ} \mathrm{C}$ was possibly produced in the groundmass after dome formation.

Our study revealed that the exogenous lava samples contain larger amounts of titanomagnetite with $T_{\mathrm{c}}=380-400^{\circ} \mathrm{C}$ than the endogenous samples. This titanomagnetite seems to be derived from the mixed magma about $900^{\circ} \mathrm{C}$. The exogenous growth occurred when the effusion rate of the lava was high (Nakada et al., 1999). During the exogenous growth, magma was squeezed out relatively quickly from the chamber and rapidly cooled. There are little amount of microphenocrysts in the glassy groundmass. Therefore, titanomagnetite from the mixed magma probably becomes dominant. On the other hand, the endogenous lava was effused slowly and abundant microphenocrysts were crystallized during the eruption. It is suggested that Ti-poor titanomagnetite was crystallized at low temperature and the relative amount of titanomagnetite from the mixed magma becomes small. These results are consistent with microscopic observation, which indicates the endogenous dome lava shows higher groundmass crystallinity than the exogenous dome lava. This difference of groundmass crystallinity was also identified by magnetic analyses. Magnetic granulometry revealed that the dominant grain size of endogenous samples is smaller than that of exogenous samples.

This study has demonstrated that three titanomagnetites in the 1991-1995 Unzen dacite are probably caused by magma mixing and eruption process. Another study of our group revealed that two lava flows in 1663 and 1792 also contain two kinds of titanomagnetite with different $T_{\mathrm{c}}$ (Saito et al., 2006). Curie temperature of one of the titanomagnetites was estimated about $460-470^{\circ} \mathrm{C}$, which is the same value as the second titanomagnetite of the 1991-1995 lava, 
and this titanomagnetite was contained in both lava flows. This suggests that the shallow magma chamber, whose temperature is estimated about $780-820^{\circ} \mathrm{C}$, exists over several hundred years. The other titanomagnetite showed lower $T_{\mathrm{c}}$ and the value differed between the two lava flows. This suggests that temperature of the mixed magma differ among the three recent eruptions, resulting in different modes of eruption.

\section{Conclusions}

The 1991-1995 dacite at Unzen volcano exhibits distinct magnetic petrologic behaviors associated with magma mixing and eruption processes. Three kinds of titanomagnetite with different Curie temperature are identified by rock magnetic analyses. Titanomagnetites with $T_{\mathrm{c}}=460-500^{\circ} \mathrm{C}$ and $380-400^{\circ} \mathrm{C}$ are the predominant minerals. Small amounts of titanomagnetite with $T_{\mathrm{c}}=\sim 540^{\circ} \mathrm{C}$ is also present. The equilibrium temperatures of $900-920^{\circ} \mathrm{C}, 780-820^{\circ} \mathrm{C}$ and $720^{\circ} \mathrm{C}$ are estimated from titanomagnetites with $T_{\mathrm{c}}=380$ $400^{\circ} \mathrm{C}, 460-500^{\circ} \mathrm{C}$ and $\sim 540^{\circ} \mathrm{C}$, respectively. The exogenous lava samples contain more titanomagnetite with $T_{\mathrm{c}}=380-400^{\circ} \mathrm{C}$ and less microphenocrysts of titanomagnetites than the endogenous samples.

These results are explained as follows. Titanomagnetite with $T_{\mathrm{c}}=460-500^{\circ} \mathrm{C}$ was derived from low temperature felsic magma in a shallow magma chamber. Mixed magma was produced by intrusion of high temperature mafic magma resulting in the crystallization of titanomagnetite with $T_{\mathrm{c}}=380-400^{\circ} \mathrm{C}$. Finally, after being squeezed out from the magma reservoir, small amounts of titanomagnetite with $T_{\mathrm{c}}=\sim 540^{\circ} \mathrm{C}$ were crystallized. The exogenous lava effused quickly and few microphenocrysts were crystallized during eruption, resulting in the dominance of titanomagnetite from the mixed magma. On the other hand, the endogenous lava was effused slowly and abundant microphenocrysts were crystallized, resulting in smaller relative amount of titanomagnetite from the mixed magma and smaller dominant grain size of titanomagnetite.

Acknowledgments. We are grateful to Prof. H. Kamata with whom we carried out some previous works. We would like to thank Prof. M. Torii for valuable comments and suggestions through this work. We also thank Dr. T. Sugimoto, Dr. S. Noguchi and Dr. K. Furukawa for their help in the field work. Dr. Sugimoto helpfully informed us about petrologic studies of the 1991-1995 Unzen dacite. Prof. A. Hayashida and Dr. K. Fukuma were acknowledged for kind permission to use Kappabridge susceptibility meter in their laboratory. We also acknowledge helpful suggestions about rock magnetism by Dr. Y. Yamamoto. Comments of Prof. M. E. Evans, Prof. B. Moskowitz and an anonymous reviewer were highly appreciated. This study was supported by the Earthquake Research Institute cooperative research program, University of Tokyo. T. Saito is supported by Research Fellowships of the Japan Society for the Promotion of Science for Young Scientists.

\section{References}

Audunsson, H., S. Levi, and F. Hodges, Magnetic property zonation in a thick lava flow, J. Geophys. Res., 97, 4349-4360, 1992.

Dunlop, D. J. and Ö. Özdemir, Rock Magnetism: Fundamentals and Frontiers, 573 pp., Cambridge University Press, Cambridge, 1997.

Frost, B. R., Magnetic petrology: factors that control the occurrence of magnetite in crustal rocks, in Oxide Minerals: Petrologic and Magnetic Significance, edited by D. H. Lindsley, pp. 489-509, Reviews in Mineralogy, vol. 25., Mineralogical Society of America, 1991.
Holtz, F., H. Sato, J. Lewis, H. Behrens, and S. Nakada, Experimental petrology of the 1991-1995 Unzen dacite, Japan. Part 1: phase relations, phase composition and pre-eruptive conditions, J. Petrol., 46, 319-337, 2005.

Hoshizumi, H., K. Uto, and K. Watanabe, Geology and eruptive history of Unzen volcano, Shimabara Peninsula, Kyushu, SW Japan., J. Volcanol. Geotherm. Res., 89, 81-94, 1999.

Hunt, C. P., B. M. Moskowitz, and S. K. Banerjee, Magnetic properties of rocks and minerals, in Rock Physics and Phase Relations: A Handbook of Physical Constants, vol. 3, edited by T. J. Ahrens, pp. 189-204, American Geophysical Union, Washington, DC, 1995.

Kontny, A., C. Vahle, and H. de Wall, Characteristic magnetic behavior of subaerial and submarine lava units from the Hawaiian Scientific Drilling Project (HSDP-2), G-cubed 3, 8, 10.1029/2002GC000304, 2003.

Lowrie, W., Identification of ferromagnetic minerals in a rock by coercivity and unblocking temperature properties, Geophys. Res. Lett., 17, 159$162,1990$.

Matsumoto, Y., Conception of Beppu-Shimabara graben, its development and problems, Mem. Geol. Soc. Jpn., 41, 175-192, 1993 (in Japanese).

Nakada, S. and Y. Motomura, Petrology of the 1991-1995 eruption at Unzen: effusion pulsation and groundmass crystallization, J. Volcanol. Geotherm. Res., 89, 173-196, 1999.

Nakada, S., H. Shimizu, and K. Ohta, Overview of the 1990-1995 eruption at Unzen Volcano, J. Volcanol. Geotherm. Res., 89, 1-22, 1999.

Nakamura, M., Continuous mixing of crystal mush and replenished magma in the ongoing Unzen eruption, Geology, 23, 807-810, 1995.

Nishi, K., H. Ono, and H. Mori, Global positioning system measurements of ground deformation caused by magma intrusion and lava discharge: the 1990-1995 eruption at Unzendake volcano, Kyushu, Japan, J. Volcanol. Geotherm. Res., 89, 23-34, 1999.

Ohta, K., A study of hot springs on the Shimabara Peninsula, Sci. Rep. Shimabara Inst. Volcanol., Fac. Sci., Kyushu Univ., 8, 1-33, 1973 (in Japanese).

Saito, T., Magnetic petrology: applications to volcanology, J. Geography, 114, 296-308, 2005 (in Japanese).

Saito, T., N. Ishikawa, and H. Kamata, Iron-titanium oxide minerals in block-and-ash-flow deposits: implications for lava dome oxidation processes, J. Volcanol. Geotherm. Res., 138, 283-294, 2004a.

Saito, T., N. Ishikawa, and H. Kamata, Magnetic petrology of Unzen volcano, Japan: implications for lava dome oxidation processes, Annuals of Disas. Prev. Res. Inst., Kyoto Univ., 47B, 785-802, 2004 b.

Saito, T., H. Kamata, and N. Ishikawa, Characteristic magnetic petrological behavior of historical lavas of Unzen volcano, Earth Monthly, 28 379-385, 2006 (in Japanese).

Sato, H., S. Nakada, T. Fujii, M. Nakamura, and K. Suzuki-Kamata, Groundmass pargasite in the 1991-1995 dacite of Unzen volcano: phase stability experiments and volcanological implications, J. Volcanol. Geotherm. Res., 89, 197-212, 1999.

Sato, H., F. Holtz, H. Behrens, R. Botcharnikov, and S. Nakada, Experimental petrology of the 1991-1995 Unzen dacite, Japan. Part 2: $\mathrm{Cl} / \mathrm{OH}$ partitioning between hornblende and melt and its implications for the origin of oscillatory zoning of hornblende phenocrysts, J. Petrol., 46, 339-354, 2005.

Spencer, K. J. and D. H. Lindsley, A solution for coexisting iron-titanium oxides, Am. Mineral., 66, 1189-1201, 1981.

Tanaka, H., H. Hoshizumi, Y. Iwasaki, and H. Shibuya, Applications of paleomagnetism in the volcanic field: a case study of the Unzen volcano, Japan, Earth Planets Space, 56, 635-647, 2004.

Taniguchi, H., S. Nakada, K. Kamata, K. Sangen, H. Kamata, and T. Matsushima, Physical measurements of pyroclastic flows in Unzen Volcano, Earth Monthly, Special Paper 15, 112-117, 1996 (in Japanese).

Tauxe, L., Paleomagnetic Principles and Practice, 299 pp., Kluwer Acad. Publ., Dordrecht, 1998.

Thompson, R. and F. Oldfield, Environmental Magnetism, 227 pp., Allen and Unwin, London, 1986.

Ui, T., N. Matsuwo, M. Sumita, and A. Fujinawa, Generation of block and ash flows during the 1990-1995 eruption of Unzen Volcano, Japan, $J$. Volcanol. Geotherm. Res., 89, 123-137, 1999.

Umakoshi, K., H. Shimizu, and N. Matsuwo, Volcano-tectonic seismicity at Unzen volcano, Japan, 1985-1999, J. Volcanol. Geotherm. Res., 112, 117-131, 2001.

Venezky, D. Y. and M. J. Rutherford, Petrology and Fe-Ti oxide reequilibration of the 1991 Mount Unzen mixed magma, J. Volcanol. Geotherm. Res., 89, 213-230, 1999.

T. Saito (e-mail: saito@bep.vgs.kyoto-u.ac.jp) and N. Ishikawa 